\title{
Production of bioethanol using agricultural waste: Banana pseudo stem
}

\author{
Snehal Ingale ${ }^{1,3}$, Sanket J. Joshi ${ }^{1,2^{*}}$, Akshaya Gupte ${ }^{1}$ \\ ${ }^{1}$ Department of Microbiology, Natubhai V. Patel College of Pure and Applied Sciences, \\ Vallabh-Vidyanagar, Gujarat, India. \\ ${ }^{2}$ Department of Biology, College of Science, Sultan Qaboos University, Sultanate of Oman. \\ ${ }^{3}$ Department of Microbiology, ARIBAS New Vallabh Vidyanagar, Gujarat, India.
}

Submitted: November 11, 2012; Approved: March 14, 2014.

\begin{abstract}
India is amongst the largest banana (Musa acuminata) producing countries and thus banana pseudo stem is commonly available agricultural waste to be used as lignocellulosic substrate. Present study focuses on exploitation of banana pseudo stem as a source for bioethanol production from the sugars released due to different chemical and biological pretreatments. Two fungal strains Aspergillus ellipticus and Aspergillus fumigatus reported to be producing cellulolytic enzymes on sugarcane bagasse were used under co-culture fermentation on banana pseudo stem to degrade holocellulose and facilitate maximum release of reducing sugars. The hydrolysate obtained after alkali and microbial treatments was fermented by Saccharomyces cerevisiae NCIM 3570 to produce ethanol. Fermentation of cellulosic hydrolysate $(4.1 \mathrm{~g} \%)$ gave maximum ethanol $(17.1 \mathrm{~g} / \mathrm{L})$ with yield $(84 \%)$ and productivity $(0.024 \mathrm{~g} \% / \mathrm{h})$ after $72 \mathrm{~h}$. Some critical aspects of fungal pretreatment for saccharification of cellulosic substrate using A. ellipticus and A. fumigatus for ethanol production by S. cerevisiae NCIM 3570 have been explored in this study. It was observed that pretreated banana pseudo stem can be economically utilized as a cheaper substrate for ethanol production.
\end{abstract}

Key words: bioethanol, banana pseudostem, Aspergillus ellipticus, Aspergillus fumigatus, Saccharomyces cerevisiae.

\section{Introduction}

Renewable energy is now capturing a good share of the worldwide headlines because of concerns about declining supplies of fossil fuels, escalating population and industrialization triggering ever-increasing demand of fuels. All over the world, governments have encouraged the use of alternative sources of energy for looming energy crisis. The higher price of oil has attracted the greater attention to biofuels, especially bioethanol, biodiesel, biohydrogen, to list a few. Biofuels may be classified under the categories of first or second generation biofuels (Naik et al., 2010). First generation biofuels are generally made from carbohydrates, lipids and oils or agroindusrial wastes using conventional technologies. Second generation biofuels are generally derived from lignocellulosic biomass including cellulosic plant biomass such as the stalks, stems, wood. Many second generation biofuels such as biohydrogen, biomethanol and mixed alcohols are under development. Today, biomass covers about $10 \%$ of the world's primary energy demand. Against a backdrop of rising crude oil prices, depletion of resources, political instability in producing countries and environmental challenges, biomass has high potential to replace the supply of an energy hungry civilization including India. India is amongst rapidly expanding large economy, facing a formidable challenge to meet its energy needs to support its growing population. India needs to generate two - to three fold more energy than the current output (Gopinathan and Sudhakaran, 2009). At the current level of production and consumption, it seems to be highly difficult target to meet. Thus, it is must for countries like India to invest in to renewable energy options. At present, sugar and starch based raw materials and cereal grains are used for the production of bioethanol. In India, population already reached a billion and thus food security 
is a national priority and hence India cannot afford to use cereal grains for ethanol production as is commonly done in other biofuel promoting countries in Europe and USA. So, the available sources are plant biomass which is an abundant and renewable source of energy-rich carbohydrates which can be efficiently converted by microbes into biofuels of which, bioethanol is widely produced on an industrial scale today (Antoni et al., 2007). The pretreatment of lignocelluloses is known to be a key to the fast enzymatic hydrolysis of cellulose. In the past few years, a significant attention has been paid to the new sources of vegetable fibers, alternative to wood raw materials, for the pulp and paper applications and biocomposites. Banana (Musa acuminata), a monocotyledonous annual herbaceous plant, can be a suitable crop for these types of applications. India is the second largest producer of fruit in the world. Banana is the most important fruit crop of India having great socioeconomic significance, and it contributes to $27 \%$ of world's banana production (Mohapatra et al., 2010). It contributed $31 \%$ of the total food production in India. World production of banana is estimated at 48.9 million tones out of which 10.4 million tonnes, is contributed by India. India is the largest producer of bananas in the world followed by Brazil, Ecuador, Philippines, and China (http://faostat3.fao.org/home/index.html\#VISUALIZE).

Each hectare of banana crop generates nearly 220 tons of plant residues that consist mainly of lignocelluloses material. In countries like India, where $4.796 \times 10^{5}$ ha of banana is cultivated, farmers discard banana waste into rivers, lake and on roads, causing serious environmental problems. An environmentally friendly solution and alternative economic use for this agricultural residue is needed. The main residuals of banana crops are leaves and pseudo stem, both containing high levels of lignocelluloses.

As part of our study of cost effective means of producing fuels from biomass, we have reported a process for producing ethanol from lignocellulosics prehydrolysed by alkali followed by saccharification carried by co-cultivation of Aspergillus fumigatus and A. ellipticus and fermentation of the released sugars to ethanol, using a yeast strain Saccharomyces cerevisiae NCIM 3570 in five liter capacity bioreactor designed for ethanol production.

\section{Materials and Methods}

\section{Microorganisms and culture conditions}

A. fumigatus and A. ellipticus strains reported to produce cellulases (Gupte and Madamwar, 1997) were maintained on potato dextrose agar (PDA) medium and were revived once in a month on PDA slants at $30 \pm 2{ }^{\circ} \mathrm{C}$ for 7 days and were stored at $4{ }^{\circ} \mathrm{C}$.

Yeast strain S. cerevisiae NCIM 3570 was maintained on malt extract-glucose-yeast extract-peptone (MGYP) medium (g\%): malt extract, $0.3 \mathrm{~g}$; glucose, $1.0 \mathrm{~g}$; yeast extract, $0.3 \mathrm{~g}$; peptone, $0.5 \mathrm{~g}$; agar, $2.0 \mathrm{~g}$; Adjust $\mathrm{pH}$ to
6.4-6.8. The biomass was obtained by cultivating the yeast cells in MGYP broth medium and $1 \times 10^{7}$ cells were used for inoculation into fermentation media. During the fermentation process biomass obtained was deflocculated by washing 2-3 times with sterile normal saline $(0.9 \% \mathrm{NaCl})$, prior to $\mathrm{OD}_{600}$ measurements and correlated to the cell dry weight (CDW) by a standard curve. CDW was determined by filtering $10 \mathrm{~mL}$ yeast culture through a pre-weighed 0.45 $\mu \mathrm{m}$ filter and washing with $20 \mathrm{~mL}$ water. The filter was dried overnight at $104{ }^{\circ} \mathrm{C}$, cooled in a desiccator and weighed to constant weight.

\section{Substrates for fermentation}

Banana pseudo stems were collected locally and were used as cellulosic substrates. It was milled and sieved before use to obtain a 50 mesh size. Substrate ( $5 \mathrm{~g}$ ) was subjected to different pretreatments (like alkali, acids and/or steam) for $18 \mathrm{~h}$ at room temperature. After each treatment, the cellulosic substrates were washed repeatedly with water to neutral $\mathrm{pH}$, dried overnight. Treated substrates were utilized for cellulolytic enzyme production using $A$. ellipticus and $A$. fumigatus by cocultivation using solid state fermentation. Spore number of $1 \times 10^{8}$ were used for inoculation into $20 \mathrm{~mL}$ Mendels and Webers media with $5 \mathrm{~g}$ lignocellulosic material (treated banana pseudo stem) for cellulolytic enzyme production under solid state fermentation. The composition of media was $(\mathrm{g} / \mathrm{L})$ : $\left(\mathrm{NH}_{4}\right)_{2} \mathrm{SO}_{4}, 1.4$; $\mathrm{KH}_{2} \mathrm{PO}_{4}, \quad 2.0 ; \quad \mathrm{CaCl}_{2} 2 \mathrm{H}_{2} \mathrm{O}, \quad 0.3 ; \quad \mathrm{MgSO}_{4} 7 \mathrm{H}_{2} \mathrm{O}, \quad 0.3$; $\mathrm{FeSO}_{4} 7 \mathrm{H}_{2} \mathrm{O}, 0.005 ; \mathrm{MnSO}_{4} \mathrm{H}_{2} \mathrm{O}, 0.0016 ; \mathrm{ZnSO}_{4} 7 \mathrm{H}_{2} \mathrm{O}$, 0.0014; $\mathrm{CoCl}_{2} 6 \mathrm{H}_{2} \mathrm{O}, 0.002$; Peptone, 0.1; Tween-80, 0.1 . Flasks were harvested at different incubation periods, and enzymes were extracted from the flasks. Crude enzyme filtrate from the cultured flasks was prepared by the addition of $20 \mathrm{~mL}$ of citrate buffer $(50 \mathrm{mM}, \mathrm{pH} 5)$ to the contents of each flask and shaking the contents at $150 \mathrm{rpm}$ for $30 \mathrm{~min}$. Enzyme broth was filtered using coarse filter paper (coarse grade) and filtrate obtained was centrifuged at 10,000 rpm for $15 \mathrm{~min}$. Crude enzyme extract obtained was analyzed for various enzyme activities. Cellulolytic enzymes obtained are used for carrying out saccharification and saccharified hydrolysate utilized for ethanol production.

\section{Enzymatic hydrolysis of delignified cellulosic substrate}

Enzymatic hydrolysis of $5 \mathrm{~g}$ substrate (delignified banana pseudo stem) was carried out in $90 \mathrm{~mL}$ of $0.05 \mathrm{M}$ citrate phosphate buffer ( $\mathrm{pH}$ 5.0) containing $0.005 \%$ sodium azide and slurry was acclimatized by incubating at $50{ }^{\circ} \mathrm{C}$. Thereafter, $10 \mathrm{~mL}$ crude enzyme (containing $13 \mathrm{U}$ CMCase and $4 \mathrm{U}$ FPase per g of substrate) was added to preincubated slurry and reaction continued for $48 \mathrm{~h}$. Samples were withdrawn at regular interval of $4 \mathrm{~h}$, centrifuged at 10,000 rpm for $15 \mathrm{~min}$ and the supernatant was analyzed for total reducing sugars released. The extent of hydrolysis was calculated as follows: 
$\%$ Saccharification $=($ Reducing sugar concentration obtained/ Weight of the pretreated substrate) $* 100$

\section{Analytical techniques}

Chemical composition of banana pseudo stem: The cellulose, hemicellulose and lignin were estimated by acid detergent method developed by Goering and Van soest (1975).

Reducing sugar estimation: Reducing sugars were analyzed by dinitrosalicylic acid (DNS) method (Miller, 1959). The reducing sugar concentration in the sample was calculated using the standard curve of D-glucose.

Ethanol determination: Ethanol was estimated from samples by dichromate oxidation and thiosulphate titration (Marcelle et al., 2007). Purity of ethanol produced was analyzed by gas chromatography (GC) (Perklin Elmer, Turbometrix 40 headspace sampler) with PE wax column at oven temperature of $85^{\circ} \mathrm{C}$ and flame ionization detector (FID) at $200^{\circ} \mathrm{C}$. Nitrogen was used as a carrier gas with a flow rate of $0.5 \mathrm{~mL} / \mathrm{min}$. The ethanol standards were prepared using commercial grade ethanol (Merck, India).

Cellulolytic enzyme estimation: Filtrates obtained were analyzed for endo-1, 4- $\beta$-D-glucanase (CMCase) and exo-1, 4- $\beta$-D-glucanase (filter paper activity). Cellulase ac- tivity was reported in filter paper units per gram of dry substrate $(\mathrm{FPU} / \mathrm{g})$ and endoglucanase activity was determined using $1 \%$ carboxymethyl cellulose in a $\mathrm{pH} 5.0$ sodium citrate buffer using method described by Ghose (1987). One unit of enzyme was defined as the amount of enzyme required to release $1 \mathrm{mmol}$ of product (glucose equivalents for FPU and CMC) from the appropriate substrates per minute under assay conditions. All colorimetric observations were recorded using the multiprocessor-based UV-VIS Spectrophotometer (UV-1800 PC, Shimadzu, Japan).

\section{Results and Discussion}

India is amongst top five bioethanol producing countries (Demirbas, 2009). Currently bioethanol is produced from alcoholic fermentation of molasses or simple sugars, which are produced from crops generating starch or sugar. While technologies to produce ethanol from simple carbohydrates are well established, the technologies to produce bioethanol from complex lignocellulosic biomass are still under development. It is possible that agricultural waste products (like banana pseudo stem) may be economically converted to bioethanol. We used banana pseudo stem as a source of lignocellulosic substrate for ethanol production as shown in Figure 1.

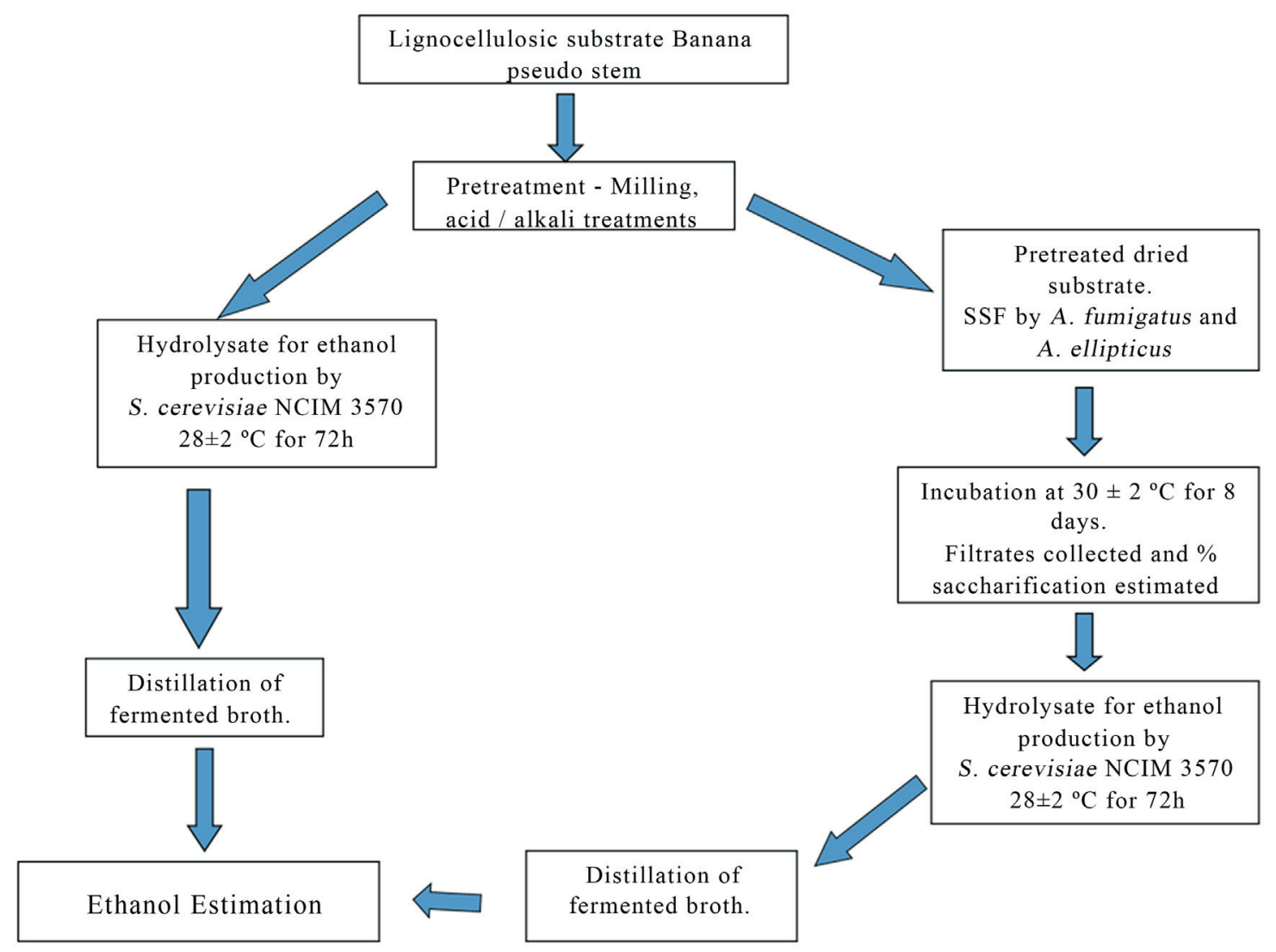

Figure 1 - Bioethanol production from banana pseudostem: Flow chart. 


\section{Effect of pretreatment processes on banana pseudo} stem

Different pretreatments, enzymatic hydrolysis, fermentation using different microbes, product separation and post-treatment of the liquid are the main steps of the currently employed ethanol production process from lignocellulosic biomass (Chang, 2007; Hendriks and Zeeman, 2009). Pretreatment processes of lignocellulose are necessary to break down lignin and increase accessibility of enzymes and microbes to carbohydrates (Demirbas, 2005; Hendriks and Zeeman, 2009). Pretreatments like concentrated acids, wet oxidation, solvents and metal complexes are effective, but too expensive as compared to the glucose costs. Steam and alkali based pretreatments are the ones that, according to the factors determining the economic effectiveness have a high potential of which, alkali pretreatment in particular has been shown to effectively remove lignin, but leave the carbohydrate portions relatively intact (Galbe and Zacchi, 2007). Various alkali and acid treatments were carried out (data not shown) of which alkali treatments $(5 \%$ plant biomass with $1 \mathrm{~N} \mathrm{NaOH}$, for $18 \mathrm{~h}$ at room temperature) were found to be optimum for delignification. The chemical composition of banana pseudo stem showed approximately $2.5-3.4 \%$ lignin; $19.3-24.4 \%$ hemicellulose; $30.3-35.2 \%$ cellulose and $7.3-10.7 \%$ ash (Figure 2).

\section{Enzyme production by co-cultivation of $A$. ellipticus and $A$. fumigatus}

A. ellipticus and A. fumigatus exhibiting cellulolytic activities (Gupte and Madamwar, 1997) were used in the study for the saccharification of alkali treated banana pseudo stem by co-cultivation. Gupte and Madamwar (1997) have reported production of cellulolytic enzymes on bagasse under solid state fermentation by co-culture of $A$. ellipticus and $A$. fumigatus. They observed improved hydrolytic and $\beta$-glucosidase activities under co-culture ex- periments as compared to when each strains were used separately, and maximum enzyme production was observed after $8 \mathrm{~d}$ of fermentation process. We also observed maximum enzyme activity at $8^{\text {th }}$ day of fermentation process on banana pseudo stem. Maximum CMCase and FPase observed were 13.15 and $4.05 \mathrm{U} / \mathrm{g}$ of substrate respectively, on $8^{\text {th }}$ day (Figure 3 ).

\section{Saccharification \% and ethanol production}

Two sets of treatments were used for saccharification: 'alkali treated' and 'alkali + enzyme treated' banana pseudo stem. Alkali $(1 \mathrm{~N} \mathrm{NaOH})$ treated substrate was neutralized and the liquid was used for ethanol production, using $S$. cerevisiae NCIM 3570 . Whereas, for enzyme treatment, the alkali-treated banana pseudo stem $(5 \mathrm{~g})$ was resuspended in $90 \mathrm{~mL}$ of sodium citrate buffer (pH 5.0). Crude enzyme extract $(10 \mathrm{~mL}$ containing $13 \mathrm{U}$ CMCase and $4 \mathrm{U}$ FPase per $\mathrm{g}$ of substrate) was added to the above slurry to initiate saccharification in a water bath at $50^{\circ} \mathrm{C}$.

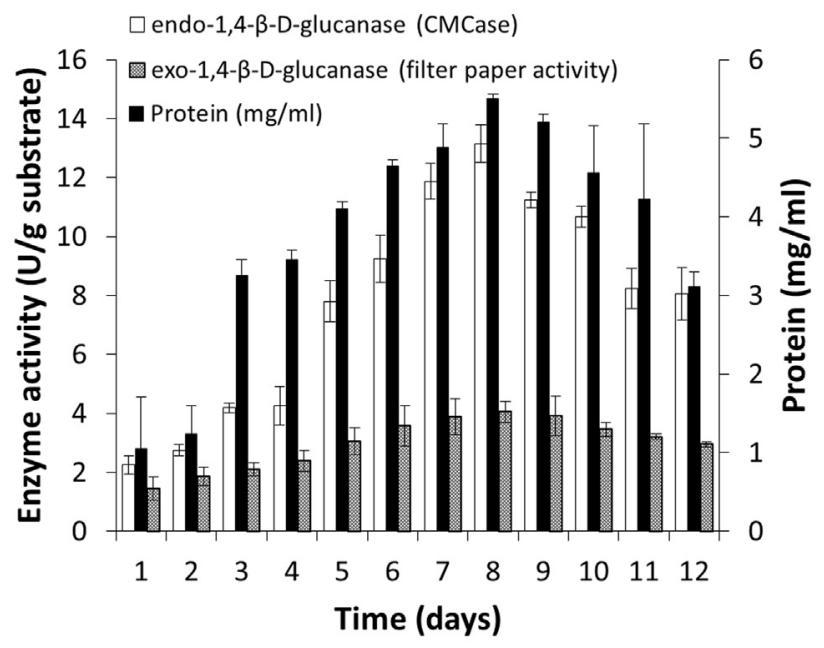

Figure 3 - Cellulolytic enzyme production profile during co-cultivation of A. ellipticus and A. fumigatus under solid state fermentation.

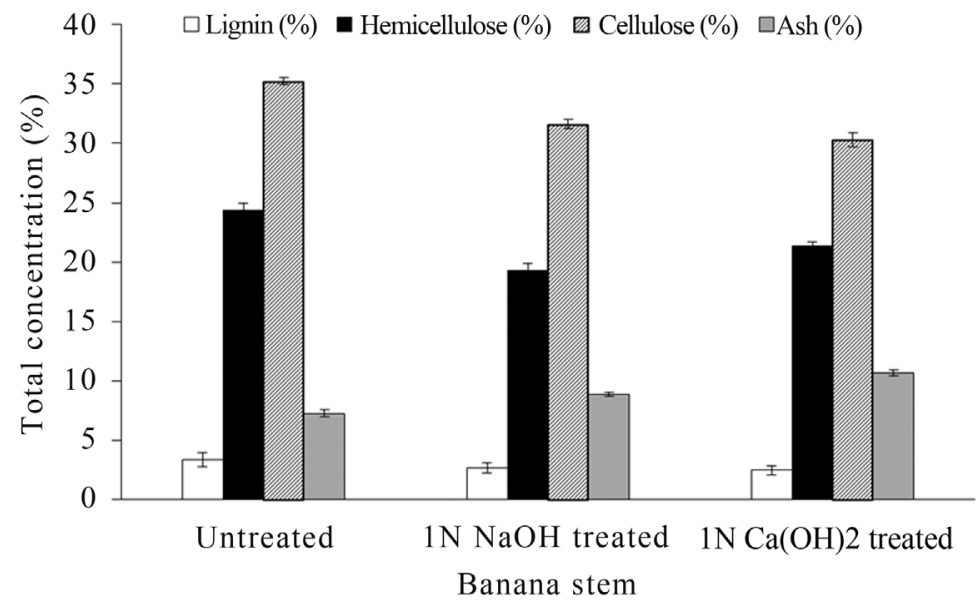

Figure 2 - The approximate chemical composition of banana pseudo stem. 
Aliquots were collected at every $4 \mathrm{~h}$ for sugar analysis and were analyzed for reducing sugars using DNS method (Miller, 1959). During the time course of enzymatic saccharification of delignified banana pseudo stem, a regular increase in release of sugars was observed till $36 \mathrm{~h}$ of incubation, and maximum saccharification was observed at $48 \mathrm{~h}$ of incubation (Figure 4). Thus saccharified hydrolyzate was used for ethanol production using $S$. cerevisiae NCIM 3570. The reducing sugars released after alkaline hydrolysis and 'alkali + enzyme treatment' were $203 \pm 8.3$ $\mathrm{mg} \%$ and $833 \pm 9.6 \mathrm{mg} \%$ respectively, which accounts for $4 \%$ and $41 \%$ saccharification respectively. Thus, alkali treatment followed by enzymatic saccharification released more reducing sugars, than alkali treatment. When those hydrolyzed liquid was used for ethanol fermentation by $S$. cerevisiae, $14.4 \pm 0.8 \mathrm{mg}$ and $190 \pm 1.3 \mathrm{mg}$ of ethanol was produced, from respective hydrolysates (Figure 5).

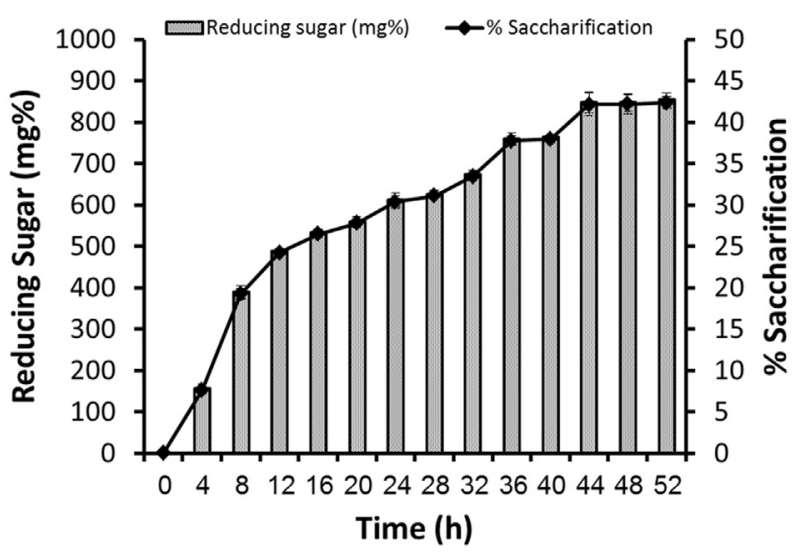

Figure 4 - Enzymatic saccharification time-course of alkali treated banana pseudostem.

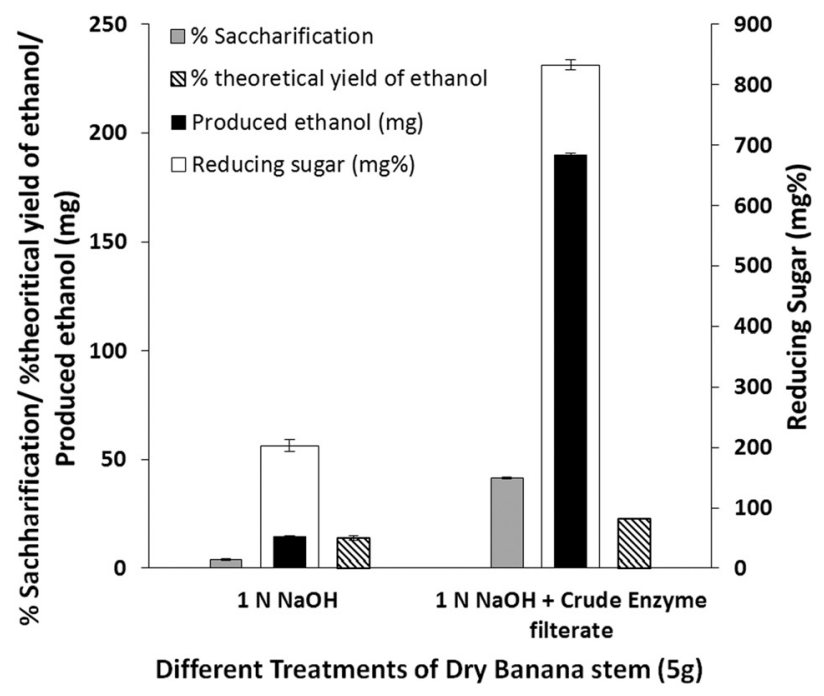

Figure 5 - Saccharification \% and ethanol yield from 'alkali' and 'alkali + enzyme' treated banana pseudostem.
Walsum et al. (1996) studied the conversion of pretreated lignocellulosics $\left(20{ }^{\circ} \mathrm{C}, 5 \mathrm{M}\right.$ Pa for $\left.120 \mathrm{~s}\right)$ with liquid hot water (LHW) to ethanol by simultaneous saccharification and fermentation (SSF) using S. cerevisiae in presence of Trichoderma viride. SSF of sugarcane bagasse, aspen chips $(3 \mathrm{~mm})$ and hardwood flour $(70 \mathrm{mesh})$ resulted in $90 \%$ conversion to ethanol in 2-5 days at enzyme loadings of 15-30 FPU/g. Clarkin and Clesceri (2002) evaluated commercial celluloses using enzymatic and physical methods of pretreatment. The reducing sugars released by the cellulase of T. viridae ranged from 135.37 to $244.48 \mathrm{mg} /$ day. In present study, the reducing sugars released by the cellulases produced during co-cultivation of $A$. ellipticus and $A$. fumigatus on banana pseudo stem ranged from 800 to $833 \mathrm{mg} / \mathrm{mL}$ in 36-48 h incubation. Baig et al. (2004) investigated the saccharification of banana agro-waste by cellulases of Trichoderma lignorum. The steam treated agrowaste yielded $1.34 \mathrm{mg} / \mathrm{mL}$ of reducing sugars after $24 \mathrm{~h}$. Several other reports highlights the use of co-culture enzymatic degradation of lignocellulosic by-products and its fermentation by yeasts (Table 1).

\section{Lab scale bioreactor for ethanol production}

To increase the initial concentration of reducing sugar in the hydrolysate obtained from $\mathrm{NaOH}$ and enzyme treated banana pseudo stem, it was further concentrated using rotary evaporator (Buchi, Switzerland). The concentrated hydrolysate (4.1 $\mathrm{g} \%$ sugar) was used for ethanol production in lab-scale bioreactor (5 1 capacity glass bioreactor) with working volume 3.51 . It was inoculated with 5\% inoculum of yeast cells. The enzymatic hydrolysate was further supplemented with $(\mathrm{g} / \mathrm{L}):\left(\mathrm{NH}_{4}\right)_{2} \mathrm{SO}_{4} 0.5 ; \mathrm{KH}_{2} \mathrm{PO}_{4} 0.5$; yeast extract 2.5; pH 5.5 and incubated at $30^{\circ} \mathrm{C}$, without aeration and agitation for $72 \mathrm{~h}$. The samples were collected at different intervals and centrifuged at $10,000 \mathrm{rpm}$ at $4{ }^{\circ} \mathrm{C}$ for $10 \mathrm{~min}$ and the cell free supernatant was used for ethanol analysis. Fermentation of cellulosic hydrolysate $(4.1 \mathrm{~g} \%)$ using $S$. cerevisiae, reached maximum ethanol $(17.1 \mathrm{~g} / \mathrm{L})$ with $84 \%$ yield ( $\mathrm{g}$ of ethanol/100 $\mathrm{g}$ sugar) and ethanol productivity of $0.024 \mathrm{~g} \% \mathrm{~h}$, and the biomass was found to be around $0.84 \mathrm{~g} \%$ (Table 2). Sugar utilization and ethanol production was at faster rate till $48 \mathrm{~h}$. The purity of the produced ethanol was analyzed by GC. Hill et al. (2006) used various criteria like net energy gain, environmental benefits, economically competitiveness, and be producible in large quantities without reducing food supplies, for biofuel as a viable alternative. They used those criteria to evaluate, through life-cycle accounting, ethanol from corn grain and biodiesel from soybeans and reported that ethanol yields $25 \%$ more energy than the energy invested in its production, whereas biodiesel yields $93 \%$ more. Whereas they also reported that global demand for food and for transportation fuels is expected to increase more than 50 times, so there is a great need for renewable energy supplies that do not compete with food supply. Biofuels that are not food- 
based or produced from agricultural residues are likely to be of far greater importance over the longer term. Zymomonas has higher sugar uptake and ethanol yield and known to divert the less of sugars to its biomass production compared to other yeasts (Gunasekaran and Chandraraj, 1999). Davis et al. (2005) observed ethanol production of $28 \mathrm{~g} / \mathrm{L}$ by Zymomonas mobilis ZM4, when the hydrolysate of wheat stillage was supplemented with $5 \mathrm{~g} / \mathrm{L}$ yeast extract and $40 \mathrm{~g} / \mathrm{L}$ glucose with residual xylose of $2.6 \mathrm{~g} / \mathrm{L}$. Sreenath et al. (2001) reported greater ethanol production by Candida shehatae than Pichia stipites, due to increased uptake of xylose, glucose, mannose and galactose. Kourkoutas et al. (2002) reported continuous alcohol fermentation using alcohol-resistant psychrophilic $S$. cerevesiae AXAZ-1 strain, immobilized on apple-cuts for up-to 95 days and they observed continuous alcohol productivity. Sree et al. (2000) reported isolation of thermotolerant, osmotolerant $S$. cerevisiae strains from soil samples near thermal power plant, which produced $60-70 \mathrm{~g} / \mathrm{L}$ ethanol at up-to $44{ }^{\circ} \mathrm{C}$. The yeast strains like those are economically quite important for alcohol production during hot seasons and high temperatures. Velásquez et al. (2010) reported the study on an energy analysis for the ethanol production from the hydrolysis of starch and cellulosic and hemicellulosic material present in the banana fruit and its residual biomass. They considered banana plant cultivation, feedstock transport, hydrolysis, fermentation, distillation, dehydration, residue treatment and utility plant, and the analysis showed the processes can be considered energetically feasible. In present work, we report saccharification of banana pseudo stem using co-culture and its use as a substrate for ethanol production. We observed $17.1 \mathrm{~g} / \mathrm{L}$ ethanol produced from the hydrolysed and treated banana pseudostem, which are almost equivalent to other reports (Suryawati et al., 2008, 2009).

\section{Conclusion}

In country like India, where population already reached billion, curbing or managing usage of crude oil based fuels or finding the biofuels based alternative is an urgent need. Cereal grains or edible oil based biofuels are also not affordable, as they are food commodities. Under these circumstances, abundant lignocellulose based plant biomass is the best available option to be explored for production of biofuels. Banana (Musa acuminata) is a major fruit in India and which results in accumulation of cellulosic biomass waste in agricultural practices, which could serve as novel material for the production of ethanol. Fermentation of banana pseudo stem to ethanol is very encouraging and an attractive alternative technology for the production of biofuels using cellulolytic fungi and yeast. We used two cellulase producing fungal strains $A$. fumigatus and A. ellipticus under co-culture fermentation on banana pseudostem to release reducing sugar, which

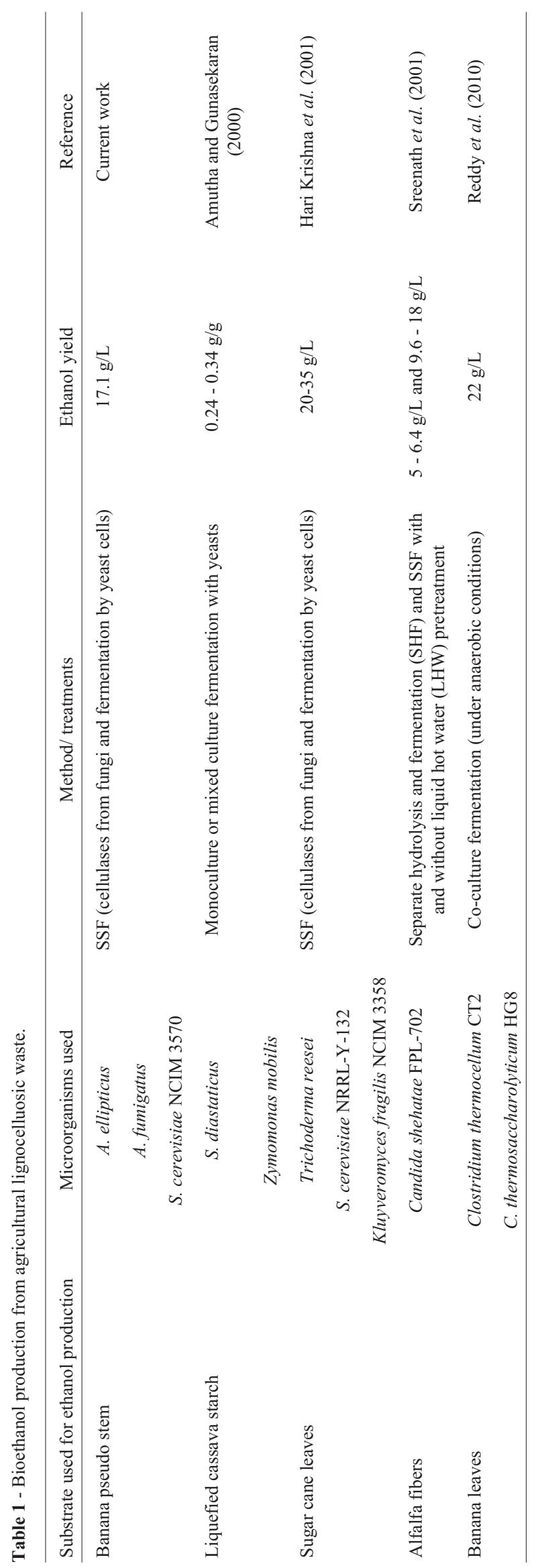




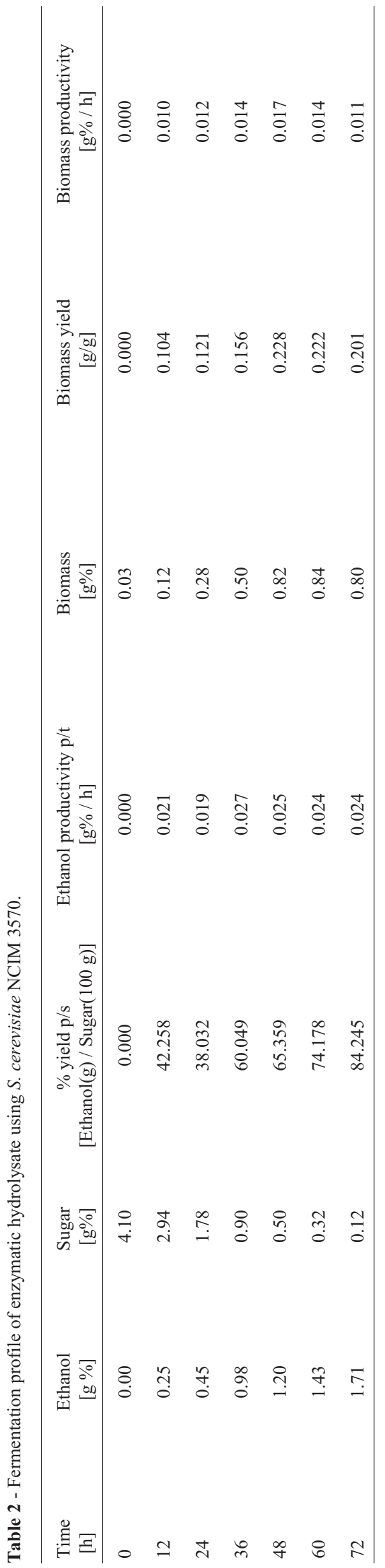

was later used as a substrate for ethanol production by yeast strain $S$. cerevisiae NCIM 3570 . The yeast gave maximum ethanol $(17.1 \mathrm{~g} / \mathrm{L})$ with $84 \%$ yield and $0.024 \mathrm{~g} \% / \mathrm{h}$ productivity, using this hydrolysate. There is still a need to develop: more efficient and economic pretreatment process; a hyper-cellulase producing strain for improved saccharification and, an improved yeast strain capable of utilizing both pentose and hexose sugars, which in turn would increase ethanol production.

\section{Acknowledgments}

SI acknowledges the funding by University Grants Commission (UGC) - Pune, India. (Letter No. 47-141 /07).

\section{References}

Amutha R, Gunasekaran P (2000) Improved ethanol production by a mixed culture of Saccharomyces diastaticus and Zymomonas mobilis from liquefied cassava starch. Ind J Microbiol 40:103-107.

Antoni D, Zverlov VV, Schwarz WH (2007) Biofuels from microbes. Appl Microbiol Biotechnol 77:23-35.

Baig MMV, Baig MLB, Baig MIA, Yasmeen M (2004) Saccharification of banana agro-waste by cellulolytic enzymes. Afri J Biotechnol 3:447-450.

Chang MCY (2007) Harnessing energy from plant biomass. Curr Opin Chem Biol 11:677-684.

Clarkin SD, Clesceri LS (2002) Enzymatic hydrolysis and cellulose based ion-exchange powdered mixed resins. Appl Microbiol Biotechnol 60:485-488.

Davis L, Jeon Y, Svenson C, Rogers P, Pearce J, Peiris P (2005) Evaluation of wheat stillage for ethanol production by recombinant Zymomonas mobilis. Biomass Bioener 29:49-59.

Demirbas A (2005) Bioethanol from cellulosic materials: A renewable motor fuel from biomass. Ener Sour 27:327-337.

Demirbas A (2009) Biofuels securing the planet's future energy needs. Ener Conv Man 50:2239-2249.

Food and Agriculture Organization of the United Nations (FAOSTAT). 2013. Banana's production of top 5 producers (Average 1992-2011). Available at: http://faostat3.fao.org/home/index.html\#VISUALIZE. Accessed May 2013.

Galbe M, Zacchi G (2007) Pretreatment of lignocellulosic materials for efficient bioethanol production. Adv Biochem Eng/Biotechnol 108:41-65.

Ghose TK (1987) Measurement of cellulase activities. Pure Appl Chem 59:257-268.

Goerging HD, Van Soest JP (1975) Forage fibre analysis, US Department of Agriculture. Agri Res Ser Washington, D.C.

Gopinathan MC, Sudhakaran R (2009) Biofuels: opportunities and challenges in India. In Vitro Cell Dev Biol- Plant 45:350-371.

Gunasekaran P, Chandraraj K (1999) Ethanol fermentation technology - Zymomonas mobilis. Cur Sci 77:56-68.

Gupte A, Madamwar D (1997) Production of cellulolytic enzymes by coculturing of Aspergillus eilipticus and Aspergillus fumigatus grown on bagasse under solid state fermentation. Appl Biochem Biotechnol 62:267-274.

Hari Krishna S, Reddy TJ, Chowdary GV (2001) Simultaneous saccharification and fermentation of lignocellulosic wastes 
to ethanol using a thermotolerant yeast. Bioresour Technol 77:193-196.

Hendriks ATWM, Zeeman G (2009) Pretreatments to enhance the digestibility of lignocellulosic biomass. Bioresour Technol 100:10-18.

Hill J, Nelson E, Tilman D, Polasky S, Tiffany D (2006) Environmental, economic, and energetic costs and benefits of biodiesel and ethanol biofuels. Proc Nat Acad Sci 103:1120611210.

Kourkoutas Y, Koutinas AA, Kanellaki M, Banat IM, Marchant R (2002) Continuous wine fermentation using a psychrophilic yeast immobilized on apple cuts at different temperatures. Food Microbiol 19:127-134.

Marcelle A, Betty-Jayne de Vos, Visser MS (2007) The preparation, assay and certification of aqueous ethanol reference solutions. Accred Qual Assur 12:188-193.

Miller GL (1959) Use of dinitrosalicylic acid reagent for determination of reducing sugar. Anal Chem 31:426-428.

Mohapatra D, Mishra S, Sutar N (2010) Banana and its by-product utilization: an overview. J Sci Indus Res 69:323-329.

Naik SN, Goud VV, Rout PK, Dalai AK (2010) Production of first and second generation biofuels: A comprehensive review. Renew Sustain Energy Rev 14:578-597.

Reddy HKY, Srijana M, Reddy MD, Reddy G (2010) Coculture fermentation of banana agro-waste to ethanol by cellulolytic thermophilic Clostridium thermocellum CT2. Afri J Biotechnol 9:1926-1934.
Sree NK, Sridhar M, Suresh K, Banat IM, Rao LV (2000) Isolation of thermotolerant, osmotolerant, focculating Saccharomyces cerevisiae for ethanol production. Bioresour Technol 72:43-46.

Sreenath HK, Koegal RG, Moldes AB, Jeffries TW, Straub RJ (2001) Ethanol production from alfalfa fibre fractions by saccharification and fermentation. Proc Biochem 36:1199-1204.

Suryawati L, Wilkins MR, Bellmer DD, Huhnke RL, Maness NO, Banat IM (2008) Simultaneous saccharification and fermentation of Kanlow switchgrass pretreated by hydrothermolysis using Kluyveromyces marxianus IMB4. Biotechnol Bioeng 101:894-902.

Suryawati L, Wilkins MR, Bellmer DD, Huhnke RL, Maness NO, Banat IM (2009) Effect of hydrothermolysis process conditions on pretreated switchgrass composition and ethanol yield by SSF with Kluyveromyces marxianus IMB4. Proc Biochem 44:540-545.

Velásquez-Arredondo HI, Ruiz-Colorado AA, De Oliveira junior S (2010) Ethanol production process from banana fruit and its lignocellulosic residues: Energy analysis. Energy 35:3081-3087.

Walsum GP, Laser MS, Lynd LR (1996) Conversion of lignocellulosics pretreated with liquid hot water to ethanol. Appl Biochem Biotechnol 17:57-58.

All the content of the journal, except where otherwise noted, is licensed under a Creative Commons License CC BY-NC. 